\title{
Early seismicity \\ of the Scottish Borders Region
}

\author{
Roger M.W. Musson \\ British Geological Survey, Edinburgh, U.K.
}

\begin{abstract}
This paper considers the seismicity of Southern Scotland and Northern England up to the year 1750. This area was formerly a border area between two states that eventually became politically united. Much of the area is uplands, and the seismicity is moderate to low. This makes for some problems in studying historical seismicity, yet the area provides a number of case studies of general interest in the field of historical seismology, including a rare case of being able to track down a «missing» earthquake.
\end{abstract}

Key words historical earthquakes - British seismicity - Scotland - England - border seismicity

\section{Introduction}

The purpose of this paper is to examine the early historical seismicity of the Scottish Borders, that is, Southern Scotland and Northern England. The main intent of the paper is to examine the problems pertaining to the pre-newspaper period (before about 1700), but as some events relevant to the overall discussion take place in the first half of the 18th century, the terminal date for this study is set at the year 1750. The area to be considered is shown in fig. 1. The northern limit is roughly the southern edge of the Midland Valley of Scotland; the southern limit is the southern extent of the English Lake District. This area contains four Nuclear Power Plant (NPP) sites - thus the historical seismicity is of considerable practical interest.

Mailing address: Dr. Roger M.W. Musson, British Geological Survey, West Mains Road, Edinburgh EH9 3LA, U.K.; e-mail: rmwm@bgs.ac.uk

\section{Character of the study area}

The problems of investigating seismicity in border areas are well known (Stucchi, 1993). The area under consideration here is notable in that it lost its status as a border between two independent countries. From early times Scotland and England were separate countries with separate royal houses. The two countries were frequently at war with one another, with military incursions going both ways across the border. Even in times of peace, the border between the two states was a notoriously lawless place where banditry was common and local lords ruled their lands as they pleased by armed force.

However, in 1603 the English queen, Elizabeth, died without issue. The throne passed to her nearest relative, James Stewart, whose great-grandmother was the sister of Elizabeth's father. However, James also happened to be king of Scotland (James VI). When James accepted the crown of England, the two countries became united at least as regards head of state, although in most respects they remained two individual countries with their own currencies, parliaments and laws. Proper political union didn't occur until 1707 when the English and Scottish parliaments were merged.

Although, to paraphrase James VI, the borders of the realm became its middle, the charac- 




Fig. 1. The study area for this paper.

ter of the Scottish Borders area remained that of a region predominantly of wild upland terrain, much of it sparsely populated. Any study of historical seismicity has to take this into account.

\section{Source materials}

For the early period in the study area, up to around the 15th century, the predominant (if not the only) source of information on seismicity is provided by monastic chronicles. The presence or absence of information on earthquakes in these documents needs to be treated carefully.

One of the first rules of historical research is that any document used as a source should be read with consideration of the purposes for which it was written. This is especially true in the case of historical seismology because most of the material available was written for reasons entirely different to the interests of the seismologist. Because the seismologist is himself interested in the reporting of earthquakes, it is easy for him to fall into the trap of attributing the same degree of interest to the writer of a document under consideration (Musson, 1998).

This is particularly true of the medieval period. The fact that many monastic houses kept annals in which events of note were recorded, and that many of these contain mentions of earthquakes, makes it tempting to imagine a network of monastic chroniclers analogous to a seismograph network - each monk with pen poised ready to record any earthquake as it occurs. Or not record it if it was not felt.

In fact, this picture is quite false. Monastic chroniclers recorded things that they felt were of note, and what these things were, and why 
they were of note, varied. In the case of «prodigies» (remarkable occurrences) such as earthquakes, the importance of these to the medieval mind was that they were portents, either of God's wrath or coming political events.

The corollary to this is that if an earthquake is memorable because it may be a portent, it is not all that important exactly where it occurs, or how severe it is. The important thing is the date of its occurrence, and this is probably one reason why many chronicles record the occurrence of earthquakes with absolutely no details beyond the date.

Consequently, if the chronicle of a particular abbey mentions any earthquake, that does not necessarily mean the earthquake was felt at that abbey, unless this is specifically stated or there is other internal evidence to suggest this. It may be that the earthquake was newsworthy because it was felt in London, or wherever the king was at that time, or for a variety of other reasons.

On the other hand, the absence of mention of an earthquake in a chronicle is not necessarily evidence that the earthquake was not felt at that place. It may indicate that the writer himself did not feel the earthquake (for a variety of possible reasons) or that he did not consider it worth recording.

A good check can be made on the reliability of «negative evidence» in British monastic chronicles by considering the reporting of severe storms (Musson, 1987). These make a good comparison with earthquakes because, from a layman's point of view, they are far more notable phenomena. In particular, storms in Britain are more frequent than earthquakes; they do far more damage; they are observed, and cause damage, over a wider area; they last longer, and therefore are more noticeable - there is less chance that any individual will fail to observe the event through being unfavourably placed; and they cause more deaths. Following Hardman et al. (1973) one can determine that for the Scottish Borders one can expect the 50 years storm to have a maximum gust speed of $46 \mathrm{~m} / \mathrm{s}$, which is enough to do widespread damage. By contrast, the earthquake with a 50 years return period is about $4.4 M_{L}$ - probably with a maximum intensity of 5 EMS.

Therefore one would expect any medieval chronicle that concerns itself with local affairs to have more frequent reports of storms than of earthquakes. If a chronicle has few or no reports of storms, particularly where it fails to report storms known from other sources to have occurred, then there is no point in expecting the chronicle to be a reliable reporter of earthquakes. In fact, as will be seen, there are no specific accounts of earthquakes in the study area in the monastic annals, so one needs to interpret this lack of reporting in light of the nature of the documents themselves.

The early history of Scotland has greatly suffered from the almost complete lack of medieval chronicles comparable to those found in England and on the Continent. It is not that no chronicles were written in Scottish abbeys; the problem arises largely from the wholesale destruction of ecclesiastical remains in the violence that accompanied the Scottish Reformation in the mid 1500s (Maxwell, 1912). One prominent exception is the Melrose Abbey chronicle.

Within the area shown in fig. 1 there are five places where chronicles were compiled: Durham, Furness Abbey, Lanercost Abbey, Hexham Priory and Melrose Abbey. These are shown in fig. 2 and will be considered in turn. Not discussed here are some ecclesiastical works of history (the most famous being that by Bede) which are of little interest from the point of view of earthquakes as they do not record such information.

\subsection{Historia Regum Anglorum et Dacorum}

This is the title given to the chronicle compiled by Simeon (or Symeon) of Durham. It starts in time where Bede's Ecclesiastical History of the English Nation finishes (731). Up to 957 it appears to be a copy of some old Durham annals no longer extant. The following section, up to 1119 , is mostly copied from Florence of Worcester (English monastic chronicler d. 1118 - Gransden, 1974) with a few interpolations (Offler, 1958). Then from 1119 to 1129 the narrative is original. Five earthquakes are mentioned: 974 («all over England»), 1 May 1048 (Worcester, Warwick, Derby and many other places), 11 August 1089 («throughout England»), 1110 (Shrewsbury) and 28 September 1119 («in many places throughout England»). All of these are copied from Florence of 


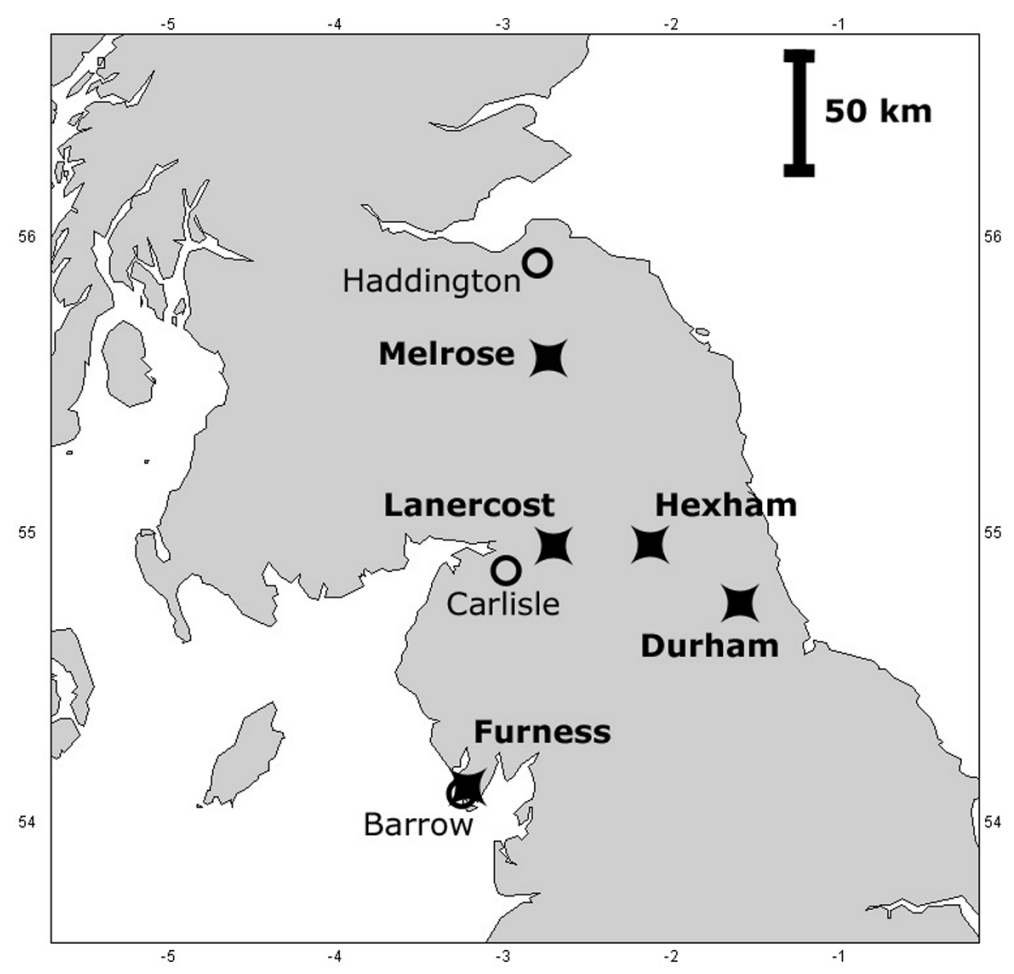

Fig. 2. Sites within the study area where extant monastic chronicles were produced, and other places in the study area mentioned in the discussion.

Worcester, except the last, which is probably copied from a continuation of Florence of Worcester. All of them are either definitely outside the study area or have such poorly-specified locations that they could have occurred anywhere in England - or even in Wales or offshore.

Only for the last ten years is this chronicle an original source, but the one earthquake mentioned (1119) is not clearly an original contribution; no unique information about it is provided. There is a mention of one storm in this final ten years, a gale on 24 December 1122 that threw down buildings.

It has been suggested (by Stevenson, 1855) that Simeon may not actually have been the author of the Historia Regum at all, as it shows uncharacteristically little interest in the affairs of Durham. However, it is still considered to be an important source for events in the North of England and South of Scotland (Arnold, 1885).

\subsection{The Furness Chronicle}

The chronicle compiled at Furness Abbey, near Barrow, is a continuation of the Historia Rerum Anglicarum of William of Newburgh, and covers the period 1198-1298. Three earthquakes are mentioned in it: 20 February 1246 («magnus et horribilis»), 23 December 1247 (no details) and 28 January 1257 («et ventus maximus»). However, it can be shown (Howlett, 1884-1889) that these are simply copied from the chronicle written in Stanley Abbey, Wiltshire, and therefore are not necessarily anything to do with Furness. The Furness chronicle is on- 
ly an original record from 1260-1298, and in this 38-years period no earthquakes are mentioned. A storm on 18 September 1268 is mentioned, as are some eclipses, but no weather phenomena are mentioned after 1272, not even the gale of 25 May 1292 which is known to have affected the NW of England (Britton, 1937).

\subsection{The Lanercost Chronicle}

Lanercost Abbey is about ten miles NE of Carlisle. The origins of its chronicle are mixed. Up until 1201 it is simply a copy of Roger of Howden's (in Yorkshire) chronicle; thereafter it is a copy of two otherwise unknown Franciscan chronicles, one 1201-1297, the other 12971346, with some extra material relating to Lanercost affairs interpolated (Gransden, 1974). The first of these was written by Richard of Durham, possibly in Haddington. The unknown continuator who produced the second chronicle probably lived in Carlisle (Gransden, 1982).

No earthquakes are mentioned in the 12011346 section of the Lanercost chronicle at all. Whilst the Richard of Durham section up to 1297 mentions a number of storms and floods affecting the Borders, the later section written in Carlisle mentions no storms.

\subsection{Hexham Chronicles}

Two chronicles were written in Hexham Priory (Raine, 1864). The first of these was by Richard of Hexham, and is no more than a short piece entitled «Account of King Stephen and the Battle of the Standard». It covers the period 1135-1139. It mentions no earthquakes.

The second, and more important work, is a continuation of Symeon of Durham's Historia Regum, by John of Hexham. It runs 1130-1153. One earthquake is mentioned, on 4 August 1133, «in pluribus Angliae partibus terrae motus factus est magnus». Since there is an eyewitness account of this event from William of Malmesbury in Wiltshire (Giles, 1904), it seems unlikely that the event had an epicentre anywhere near Hexham. No storms are mentioned, indeed the only mention by John of weather phenomena is subordinate to an account of Scottish atrocities (Britton, 1937).

\subsection{The Melrose Chronicle}

The period for which the Melrose Chronicle is an original and reliable source is 1140-1270 (Anderson, 1922). In this period only one earthquake is mentioned: in 1185 «Terremotus factus est magnus mense Aprili per Angliam». This is the earthquake that, on 15 April 1185, caused damage to Lincoln Cathedral. It is thus not likely to be an event local to Melrose - and in any case is only described as being felt in England.

Mention of storms is irregular. Leaving aside those occasions on which natural phenomena are mentioned purely for the bearing they have on political matters, the dates of tempests that are mentioned are August 1165 (in Yorkshire), 28 December 1171, 16 August 1173, 24 August 1179 (in «Helielandschire»), 1181 (England), 13 and 25 April 1206. This does not suggest that any sort of continuous or careful record was kept of local natural phenomena.

Thus, consideration of local sources for the medieval period shows two things. Firstly, that coverage is limited to the years 1119-1346, although that period is covered more or less continuously by at least one chronicle. Secondly, all the local sources are interested in human affairs almost exclusively. The lack of reports of such natural phenomena as damaging storms suggests that damaging earthquakes might equally well have gone unrecorded. It might be speculated that any occasion of really extreme earthquake damage over this period could not have gone unrecorded, but this cannot go beyond speculation. A not exceptionally severe storm can produce levels of damage comparable with an intensity of 7 EMS over a wide area; thus one can argue that the highest intensity that might reasonably go unreported is certainly no lower than 7 EMS. Even if an earthquake did occur producing this intensity value, it would still be necessary for the 7 isoseismal to be reasonably large or located in an area of population.

As to the question of a magnitude threshold for the area, above which all events are liable to have been reported, here one is even more in the 
realms of speculation. The problem is made especially difficult by the paucity of Scottish records. If the 1979 Carlisle earthquake (4.7 $M_{L}, I_{o}=6$ EMS; Musson and Henni, 2002) had occurred in 1179, it is quite conceivable it might have gone unpreserved in the annals; its effects in England South of Cumbria were limited, the damage was minor and affected only a restricted area, and the earthquake on the whole was felt more widely in Scotland than in England. A larger earthquake, felt over a larger area of England, would be more likely to be mentioned by English chronicles, but might only be accompanied with the comment that it was felt «in many parts of England». One would hope that such an earthquake would be described by at least one writer as occurring «in many parts of England and Scotland». The lack of earthquakes so described may be indicative of a lack of any such earthquakes occurring, but without comparable Scottish records this cannot be taken as certain.

\subsection{Post-monastic sources}

The dissolution of the monasteries put an end to monastic chronicles as a source of history, but the tradition had already all but died out, and given way to the writing of histories by secular authors. Some of these authors do mention the occurrence of earthquakes (e.g., Stow, 1601; Baker, 1674), but they are primarily writers of national history rather than local history.

To some extent monastic chronicles had a civic sequel in the compilation of mayoral chronicles. Just as the first monastic annals grew out of tables giving the dates of Easter, these early civic chronicles grew out of lists recording mayors, which were gradually amplified with notes about other memorable events that occurred during the term of office of each mayor.

As sources of earthquake data, these chronicles are subject to the same limitation of monastic chronicles respecting completeness. Since these documents were in no way intended by the author to be treated as a history of earthquakes, it is not valid to expect every earthquake to have been felt in a town to have been duly noted.

This can be demonstrated very clearly by referring to one mayoral chronicle in NW Eng- land. This was compiled in Kendal. An entry for 1817 reads, «Sunday morning, November 9, the shock of an earthquake felt in Kendal, this being the fifth or sixth shock here since June 1668» (Nicholson, 1861). The number of shocks mentioned previously in the chronicle is one (the 11 August 1786 Whitehaven earthquake). It appears that four or five other earthquakes felt in Kendal are missing from the record. This will be returned to in discussion of the June 1668 event.

On the other hand, it is at least more reasonable to assume that an earthquake mentioned in the town annals without any details was felt at the town in question, since the intention of the document is to record the events of that town. An earthquake occurring elsewhere would not have the same interest to a town chronicler as it might to a medieval monk.

It is in this period that miscellaneous sources begin to become useful to a study of historical seismicity - diaries, letters, memoranda, etc. The latter end of the 16th century also saw the first publication of material specifically on earthquakes, including the first British earthquake catalogue (Fleming, 1580).

In considering documentary sources, firstly, the further back in time one goes, the less written material survives. Secondly, the manuscripts most likely to survive are those that have material value, i.e. legal and financial documents. Deeds, charters and suchlike documents have no value for earthquake studies in Britain. Thus, of the amount of manuscript material preserved from past centuries, the amount containing mention of earthquakes is small.

In countries like Italy where earthquakes can destroy entire communities, financial documents can be useful sources. In cases of heavy damage, one may find repair bills and pleas for remission of taxes. If one finds documents indicative that everyday life was still going on in a community, this may suggest that destruction was not so heavy. In Britain one does not expect to find heavy destruction at all, and therefore the only documents that are useful are those that can register the occurrence of an earthquake that was no more than slightly damaging.

Since the historical end of this study is set at 1750 , early newspapers will be used for events after 1700 . The use of newspapers in historical 
earthquake studies in Britain has been discussed in detail by Musson (1986). The only two places in the study area where newspapers were published before 1750 were Dumfries and Whitehaven. Of the Drumfries [sic] Mercury but a single issue survives (8 May 1721) and of the Whitehaven Weekly Courant (started 1736) there are no surviving copies at all. Therefore one relies largely on the Edinburgh and London press for this period.

\section{Chronological list of earthquakes $\left(^{*}\right)$}

This section of the paper will present descriptions and discussions of the earthquakes in the study area up to 1750 . A summary list is provided as table I. Assessment of parameters is as discussed in Musson (1996). Once fake events have been removed (these will be discussed later) only a few events remain, though some of these are rather interesting from a historical perspective.

There are no earthquakes in the area at all for the medieval period, as already discussed. Thus it is not until the opening of the 16th century that one sees even the possibility of an earthquake in this area.

(*) In the text that follows references given in square brackets, mostly newspapers, are given completely in the text and not in the references section.

\subsection{September 1508 Borders? North Sea? Rockall?}

This earthquake presents special problems. It is conceivably one of the largest events to have affected the study area, and has been listed in previous studies as occurring in the study area (e.g., by Principia Mechanica Ltd., 1982; Ambraseys and Melville, 1983), but very little documentation of the event survives. Consequently it has been necessary to examine the little information that does exist with extreme scrutiny.

It has not been possible to trace any contemporary account of the earthquake. The nearest sources in time are the Scottish historian John Leslie, Bishop of Ross (1527-1596) and the English historian Raphael Holinshed (?1580). The third source is Sir James Balfour, writing around 1650. All these sources are summarised in table II.

Leslie's account of the earthquake survives in three forms, all of them brief. In his «History of Scotland», a work composed during imprisonment in England ca. 1568-1570, presented to Queen Mary (herself a captive at this date) in 1571 and eventually published in 1830, it is stated, «In September, ane gret erd quak wes, the xix day thairof in divers placeis, and for the maist part in the kirkis, quhilk wes asueill [as well] in Ingland as in Scotland.» (Leslie, 1830).

In 1578 Leslie revised and expanded his History and translated it into Latin, and it was published in Rome under the title «De origine

Table I. Earthquakes in the study area before 1750. Parameters in italics are very approximate estimates.

\begin{tabular}{|c|c|c|c|c|c|c|c|c|c|}
\hline Day & Month & Year & Hour & Minute & Lat. & Long. & Depth & $M_{L}$ & Location \\
\hline & & $1650\left({ }^{1}\right)$ & & & 54.98 & -2.78 & & & Cumberland \\
\hline 11 & 04 & 1650 & 17 & & 54.98 & -2.78 & & 4.9 & Cumberland \\
\hline \multirow[t]{2}{*}{27} & 04 & 1650 & & & 55.63 & -2.72 & & 3.5 & Galashiels \\
\hline & 06 & 1668 & & & 55.00 & -2.40 & & 4.4 & Borders \\
\hline \multirow[t]{2}{*}{01} & 03 & 1728 & 04 & 30 & 55.58 & -2.81 & 21 & 4.2 & Galashiels \\
\hline & 10 & 1746 & & & 55.42 & -3.77 & & $2.0\left(^{2}\right)$ & Leadhills $\left({ }^{3}\right)$ \\
\hline 14 & 02 & 1749 & 08 & 30 & 55.42 & -3.77 & & 2.7 & Leadhills $\left({ }^{3}\right)$ \\
\hline
\end{tabular}

$\left({ }^{1}\right)$ or 1649; $\left({ }^{2}\right)$ minimum likely value; $\left({ }^{3}\right)$ mining induced earthquakes. 
Table II. Summary of sources for the 1508 earthquake.

\begin{tabular}{|c|c|c|c|c|c|}
\hline$\#$ & Source & $\begin{array}{l}\text { Publication } \\
\text { date }\end{array}$ & $\begin{array}{c}\text { Approximative } \\
\text { date of composition }\end{array}$ & $\begin{array}{l}\text { Date given for } \\
\text { earthquake }\end{array}$ & $\begin{array}{l}\text { Earthquake } \\
\text { details }\end{array}$ \\
\hline 1 & $\begin{array}{l}\text { Leslie's first } \\
\text { MS history }\end{array}$ & 1830 & 1570 & 19 September 1508 & $\begin{array}{l}\text { Great, in many places in England } \\
\text { and Scotland, more in the churches }\end{array}$ \\
\hline 2 & $\begin{array}{l}\text { Leslie's printed } \\
\text { Latin version }\end{array}$ & 1578 & 1578 & 19 September 1508 & $\begin{array}{l}\text { Great, in Scotland and the whole of } \\
\text { England, specially shook churches }\end{array}$ \\
\hline 3 & Holinshed & 1578 & 1578 & 19 September 1508 & $\begin{array}{l}\text { Great, in many places in England } \\
\text { and Scotland, also felt in churches }\end{array}$ \\
\hline 4 & $\begin{array}{l}\text { Scots translation } \\
\text { of (2) by Dalrymple }\end{array}$ & $e^{1895}$ & 1596 & 19 September 1509 & $\begin{array}{l}\text { Terrible, heard throughout England } \\
\text { and Scotland, churches shook } \\
\text { vehemently }\end{array}$ \\
\hline 5 & Balfour & 1825 & 1650 & 10 September 1508 & $\begin{array}{l}\text { Dreadful, in Scotland and England, } \\
\text { lasted six minutes, caused terror } \\
\text { and astonishment }\end{array}$ \\
\hline
\end{tabular}

moribus, et rebus gestis Scotorum ...» (Leslie, 1578). In this the passage reads, «... ingens erat terrae, non solum in Scotia, verum etiam tota Anglia, motus, quo templa in primis contremuerunt, quod quidam religionis euertendae augurium interpretabantur».

This may be translated, «there was a great earthquake, not only in Scotland, but also, indeed, even the whole of England, which shook the churches especially, which was interpreted as an omen of the overthrowing of religion». The third version is Dalrymple's 1596 translation of Leslie's Latin text. This was published in 1895 , and appears to be rather free. The year of the earthquake is given as 1509 instead of 1508 , and the text reads, «... terrable Erdquakes throuch Jngland and Scotland war hard, kirkes quaket and trimblet vehementlie, quhilke mony exponet to the overthraw of religions.» (Leslie, 1895).

Holinshed's Chronicles went through many and various editions, the first being in 1578 . His entry on the earthquake comes in the Scottish chronicle, and reads, "The 19th of September was a great earthquake in manie places, both of England and Scotland, namelie, the same was perceived in churches.» (Holinshed, 1578).

Balfour's account is a little different. It reads, «1508 The 10 of September, this same zeire, a dreadful earthquack in Scotland and
England, wich lasted the 10 pairt of ane houre, to the grate terror and astonishment of all the inhabitants.» (Balfour, 1825).

Leslie and Holinshed present essentially the same information, and it seems likely they were using a common source, or (very likely) Holinshed was using Leslie. It appears that the earthquake was felt over a wide, perhaps a very wide, area, and that it was felt both in England and Scotland, and caused considerable alarm, and particularly affected churches. Balfour leaves out the detail of the churches, but adds an estimated duration of six minutes. He also describes alarm, but mentions no damage. Balfour gives a different date; possibly a transcription error.

From the fact that the earthquake was felt both in England and Scotland, Principia Mechanica Ltd. (1982) conclude the epicentre to have been somewhere in the Borders. According to Ambraseys and Melville (1983) it is an «evident that it [the epicentre] must have been in the border region».

The description that the earthquake was felt through England and Scotland is almost unique for an early historical earthquake. A consideration of Scottish seismicity in the last 300 years shows that activity is largely concentrated north of the Central Lowlands. Thus it almost never happens that a Scottish earthquake has been felt 
south of the border (the felt area of the 1839 Comrie event crossed the border by a few miles only; the 1728 Galashiels earthquake will be discussed below). Most English earthquakes that have been felt in Scotland, even the larger events, have typically only been weakly felt in the Southern Uplands, effects which would probably go unreported in the early 16th century. The principal exception was the 1979 Carlisle earthquake, which was strongly felt as far north as Glasgow. To a lesser extent the 1786 Whitehaven earthquake also fits the description (Musson et al., 1984), although the effects in Scotland of the 1786 event were nowhere as marked as those of the 1979 earthquake. Thus an earthquake similar to, and possibly larger than, the 1979 Carlisle earthquake is a plausible interpretation of the sparse evidence. If, however, such an event was really felt «verum etiam tota Anglia», it would have to have been of considerably larger magnitude than the 1979 event, and correspondingly more likely to have caused significant damage in the epicentral area, and to have impinged more strongly upon the local historical record.

It is possible that a measure of exaggeration has crept into Leslie's account. Holinshed incorporates mention of the earthquake into his Scottish chronicle, but not into his English chronicle despite the fact that he mentions that the earthquake was felt in England. This suggests he had no English sources for the event, which in turn suggests that the effects of the earthquake may have been more remarkable in Scotland than in England, and that the whole of England was not affected. Stow (1601) and Baker (1674) are both silent on the event. So are some other Scottish sources, though. The first version of Leslie's history covered only the period 1436-1561, and was intended as a continuation of the chronicle of Hector Boece (Batho and Husbands, 1941). When Leslie prepared the Latin version for publication, he took the earlier material mostly from Boece. The other main continuator of Boece, Pitscottie (lived 1532?-1578?), covered a similar period to Leslie (1436-1575), wrote at a similar time (the early 1570s), but doesn't mention the earthquake (Mackay, 1899). It would be very helpful if a coeval source for the earthquake could be located. Batho and Husbands (1941) speculate on the existence of a lost continuation of Boece by John Bellenden (Ballantyne), who translated Boece in 1531, and is thus a more contemporary figure than the others mentioned, but such a work has not been found, and its existence is conjectural.

It is curious that the main detail to be recorded by Leslie is that the earthquake was particularly felt in churches. Although churches are described as having shaken, there is no mention of damage. Possibly the earthquake occurred during the hours of service, and the effects were comparable with those of the 14 September 1777 Manchester earthquake in Lancashire churches (Burton et al., 1984). However, it should be noted that 19 September 1508 was a Wednesday (if Balfour's date were correct, it would have occurred on a Sunday, which could be taken as evidence in favour of Balfour's version).

The alternative is that churches were shaken more than houses for spectral reasons. If the earthquake were relatively large and distant, churches (with steeples) might be resonant structures, and the shock could be felt alarmingly over a wide area without any particular area of high intensity or damage. It can be mentioned that in the case of the 1580 Dover Straits earthquake, a church spire was damaged as far away as Leicestershire (Neilson et al., 1984), so the idea that churches might be particularly susceptible is not far-fetched.

An epicentre in the North Sea would be likely to be widely felt in both England and Scotland without causing significant local damage. It is possible that the 1508 earthquake may be best compared with large events in the Viking Graben such as the 24 January 1927 North Sea earthquake, which was felt over most of Scotland and in England as far South as East Anglia (Musson et al., 1986), without causing any damage. In this case, one would hope for confirmation from Norwegian sources, which is lacking. This may be due to inadequacy of the Norwegian historical record for this period.

Alternatively, a large event on the continental slope NW of Scotland, perhaps similar to the 1929 Grand Banks earthquake, is not impossible. One is naturally more inclined to propose an explanation that fits a known local precedent, so it is more credible to suggest a «prequel» of the $5.7 M_{L} 1927$ earthquake than an 


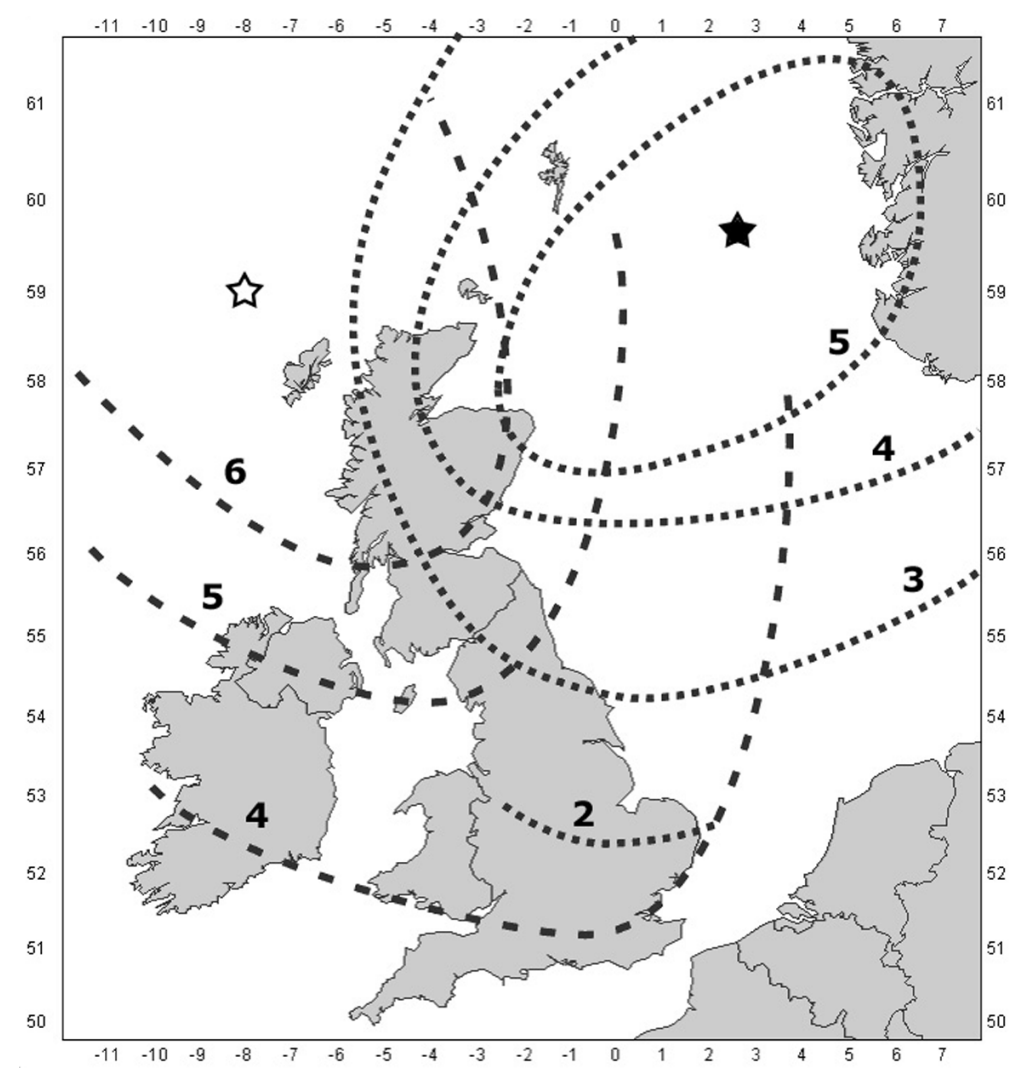

Fig. 3. Two possible analogues for the 1508 earthquake. Broad dashes indicate a worst case scenario for an occurrence of an event equal to the 1929 Grand Banks (Canada) earthquake off the NW of Scotland (open star indicates assigned epicentre); variations involving a smaller magnitude or change of isoseismal orientation can easily be imagined. Fine dashes are the isoseismals of the 1927 North Sea earthquake (black star indicates epicentre).

earthquake $>6 M_{s}$ somewhere near Rockall; but this would fit the facts perfectly well.

Figure 3 shows two possibilities. The broad dashed lines reproduce roughly the isoseismals of the Grand Banks earthquake (7.2 $\left.M_{s}\right)$ after Smith (1966), moved from the Canadian coast to a location on the passive margin indicated by the open star, and with a worst-case orientation. With a smaller magnitude or more favourable orientation of the isoseismals, any area of damage would be confined to the Gaelic-speaking NW Highlands of Scotland, an area with no literary traditions at this period. The rest of Scotland and England would only experience intensity 5 or 4 EMS, consistent with what is reported. The fine dashed lines show the isoseismals of the 1927 North Sea earthquake, after Musson et al. (1986); the black star is the instrumental epicentre (Neilson, 1980).

A large event on the continental slope as in fig. 3 might also be strongly felt in Northern Ireland. The lack of Irish reports is not necessarily significant given the political and social situation in Ireland, especially Ulster, at the time. There are, for example, no known reports at present of an earthquake felt in Antrim at a date of roughly 1600 , the existence of which is only known from an anecdote reported in a letter written in 1690, which was subsequently 
published by Wilde (1841) - although it is possible that this observation is connected with the large Scottish earthquake of 23 July 1597, if the epicentre of that event were further west than previously assumed. An earthquake nearly a century earlier could therefore be unrepresented in the historical record without stretching credulity.

In the catalogue of Musson (1994) this event is considered to be most likely a Viking Graben earthquake. The balance of probability is certainly that it was a large distant event somewhere, and not a Scottish Borders earthquake.

\subsection{April 1650 Cumberland}

Nothing else is reported from the study area during the rest of the 16th century and the first half of the 17th, so it is, in fact, not until 1650 that the first indisputable Borders earthquake occurs.

This earthquake appears in a number of catalogues, of which the earliest appears to be Turner (1696), from whence it was copied by Burton (1734). The earthquake also appears in Burton (1737) with the date incorrectly given as 1651 . Short (1749) gives earthquakes in Cumberland and Westmoreland in both 1649 and April 1650. Davison (1924) uses Short as his source and accordingly treats the event with circumspection.

The earthquake is known from two contemporary sources. The first is a broadsheet entitled «Strange newes from the north ...», printed in London on the basis of a letter received from Penrith (Anon, 1650). The second is the autobiography of Lady Anne Halkett, written some ten or twenty years after the event, but describing the earthquake at first hand (Nichols, 1875).

The information from «Strange newes from the north ...» is limited, and no specific places are mentioned, although it is reasonable to assume from the phrase «we had a general Earthquake» that the earthquake was felt at the writer's locality, i.e. Penrith (or «Penreth» in the original). The letter is dated 30 May 1650 and signed with the initials TC. The earthquake description reads as follows: «... upon the 11 of April last about 5 of the clock in the afternoon, in the Counties of Cumberland and Westmerland, we had a general Earth-quake; the people were so frightened therewith, that they forsook their houses, and some houses were so shaken that the Chimnies fell down ...» (Anon, 1650).

The following points can be drawn: i) the earthquake was widely felt in Cumberland and Westmoreland; ii) people ran outdoors in alarm; iii) some chimneys were damaged. An intensity of 6 EMS is suggested. The rest of the letter deals with political events related to the civil wars.

In the second source, Lady Anne Halkett describes two events observed at Naworth Castle (about $30 \mathrm{~km}$ north of Penrith; see fig. 4) of which the second was more severe. The text reads: "One night, being fast asleepe, I was sodainely wakened with the shaking of the bed somewhatt violent, butt of short continuance. In the morning I told Sr Ch. and my Lady that I had heard of earthquakes, butt I was confidentt I had felt one that night, and related how itt was, They laughed at me, and said I had only dreamt of itt. I could nott convince them, nor they mee; butt a litle before dinner came in some gentlemen that lived within 3 or 4 mile, and Sr Charles asked them what news: they replied the greatest they knew was that there has beene an earthquake that night, and that severall houses were shaken down with itt. Then they beleeved what I had told them. Another day my Lady H. and I was sitting together alone in my chamber, about an ell or more distant from on-another, and sodainely the roome did shake, so that both our heads knockt together. Shee looked pale like death, and I beleeve I did the same, and wee were hardly well recovered from our feares when $\mathrm{Sr} C$. came in to see how wee were, and told us hee was walking in the gallery with $\mathrm{Mr}$ $N$. and that they were so shaken they could skarce hold there feett, and was forced to hold themselves on the sides of the howse. These both hapened in the yeare 1649.» (Nichols, 1875).

Both are given as occurring some time in 1649 , but allowing for possible lapses in memory in the time between the events occurring and her account being written it is most probable that the second event was in fact the 11 April 1650 earthquake and the first a foreshock which may have occurred in 1649 or 1650 , probably the latter. It may also be recalled that in times past it was general usage for the calendar year to begin on 25 March rather than 1 Jan- 


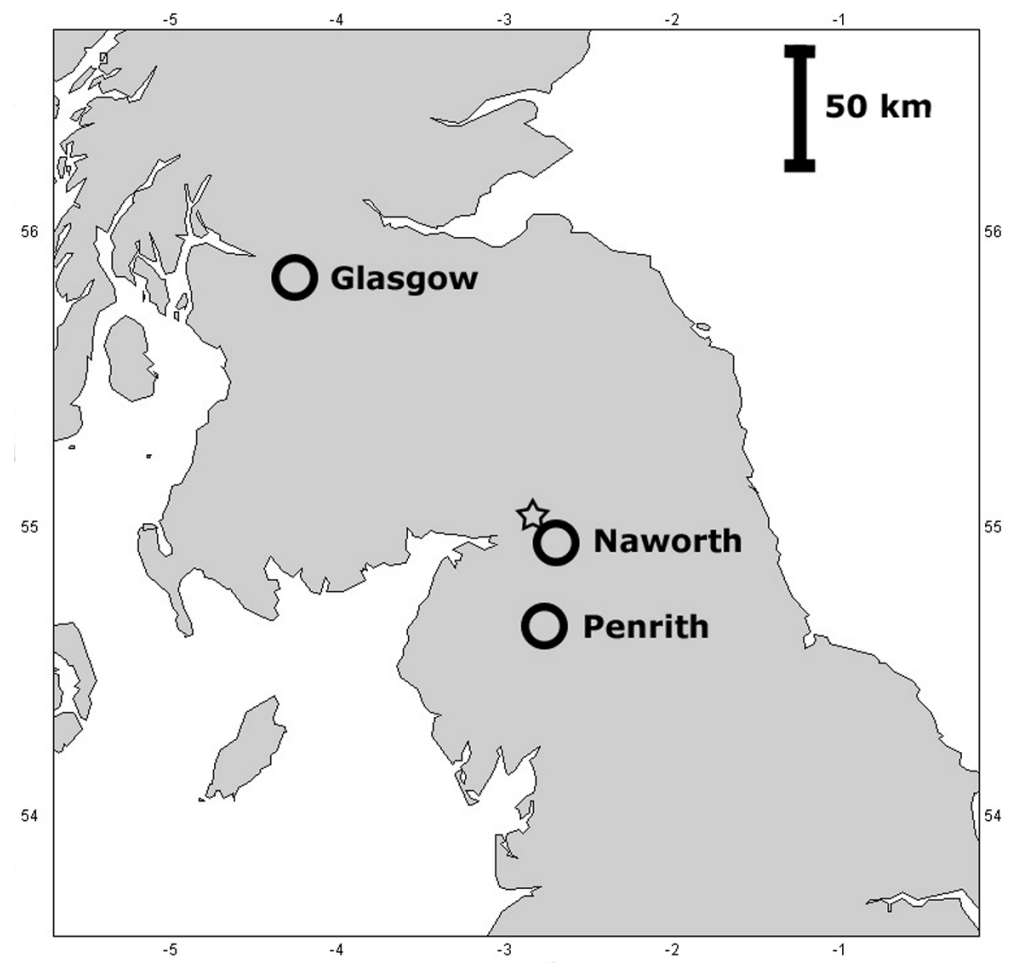

Fig. 4. Places mentioned in connection with the 11 April 1650 earthquake. The star indicates the epicentre of the 1979 Carlisle earthquake.

uary, so by this reckoning, 11 April 1650 was only seventeen days into the year. Further confirmation that the first event described by Lady Halkett was not the main shock described from Penrith is given by the times - the first event occurred during the night, while the second occurred during the day. The options are also restricted by the fact that Lady Halkett was only at Naworth Castle for a limited period - between September 1649 and June 1650. Since we know that a strong earthquake did occur at Penrith on 11 April 1650, during the time Lady Halkett was at Naworth, it would be strange if there were two additional earthquakes in 1649, neither corresponding to the Penrith event.

Lady Halkett mentions a propos of the first shock that «several houses were shaken down with it». Possibly this is another confusion of memory and this damage, near Naworth Castle, was occasioned by the second, main shock. The first event described by Lady Halkett cannot be the shock that caused damage in Penrith (i.e. be the main shock) as it was during the night, and the 11 April event was in the afternoon. Allowing for an element of exaggeration, Lady Halkett's description would suggest that the maximum intensity of the earthquake may have reached 7 EMS.

The one further piece of information comes from a Glasgow clergyman, Robert Baillie, who gives a contemporary account of an earthquake felt in Glasgow on 17 August 1656 (although he did not feel it). He mentions that he did feel an earthquake in Glasgow «in the afternoon» five or six years previously (Laing, 1841-1842). It would be highly probable that an 
earthquake felt strongly at Penrith and Naworth would also be perceptible in Glasgow; the times match; and the likelihood is that Baillie felt the 11 April 1650 earthquake.

The fact that the highest recorded intensity occurred near Naworth Castle, which is itself only about $18 \mathrm{~km}$ from the epicentre of the 1979 Carlisle earthquake, suggests that the 1650 earthquake may have originated from a similar epicentre. If it was felt at Glasgow and throughout Cumberland and Westmoreland then the felt areas of the two events are similar, and the highest intensities are certainly similar.

Earthquakes in Cumberland reportedly occurring in 1649, as in Short (1749), are due to taking the year given by Lady Halkett at face value. The problems of interpreting these fragmentary accounts are complicated even more when we turn to the next event.

\subsection{April 1650 Galashiels}

Considering that we have no record of genuine Borders earthquakes before 11 April 1650 except a likely foreshock, it seems rather strange that the next independent event should be only sixteen days later. Nevertheless, this seems to be the case. The earthquake is known from only a single source, but this source is exactly contemporary. This source is Sir James Balfour (1600-1657) again. He writes (under the heading of 1650): «The 27 of Apryle, this zeire, ther was a grate earthquake, all alonges from the head to the footte of the riuer Tueed; and in no place of this kingdome elsquhere felt, bot in these places neir adioyning to the said riuer.» (Balfour, 1825).

The River Tweed runs roughly from west to east, passing the towns of Peebles and Galashiels,



Fig. 5. Approximate felt area for the 27 April 1650 Galashiels earthquake. 
and reaching the sea at Berwick (fig. 5). Since to the north and south of the valley are ranges of hills little populated, one can estimate a felt area centred somewhere near Galashiels which is not excessively elongated and yet matches the spirit of Balfour's description that the earthquake was felt only in the Tweed Valley.

One can therefore posit an earthquake not dissimilar to the 1728 Galashiels earthquake, but a little smaller - somewhere in the region of 3.5 $M_{L}$. But was it truly a separate event? Two possibilities have to be considered: firstly that this was actually the 11 April event felt in the Tweed Valley (it would be reasonable to suppose that this earthquake was felt in that area if it was felt as far as Glasgow); secondly, that this was the earthquake felt in Glasgow in 1650 and not the 11 April event.

In considering the first possibility, if Balfour only had information from Tweeddale and not from England, and perhaps knew that the earthquake was not felt in Edinburgh, Stirling and other distant towns, he could have written as he did that the earthquake was not felt elsewhere. But he was writing around 1651 or 1652 , and there is no easy explanation as to why he should get the date wrong by sixteen days. If it were a discrepancy of seven days, one could suppose it was a confusion of weeks. If it were a discrepancy of eleven days, one could suppose it was a confusion of calendars (the Julian calendar was still in use in Britain at this time). But sixteen days one has to take at face value. Equally, the letter from Penrith fixes the date of the previous earthquake at 11 April beyond dispute. Therefore one can only conclude that this was indeed a separate earthquake.

The possibility that Baillie felt the earthquake of 27 April rather than 11 April cannot be ruled out, but is inherently less likely. It is unfortunate that Balfour gives no time of day for the 27 April event, which would make these comparisons rather easier.

Lastly, one needs to mention that Jeffrey (1857) gives the date of this earthquake as 27 April 1656, which is simply a transcription error or perhaps a misprint, as his source is Balfour.

This earthquake does not appear in Musson (1994) or any other catalogue. It shows that there are still a few historical British earth- quakes to be uncovered despite the large amount of research done since 1980.

\section{4. ? June 1668 Borders}

When discussing the completeness of earthquake catalogues, one can approach the subject in a statistical way, or one can evaluate the historical sources to try and estimate what sort of earthquake «must have been reported» at any historical period. However, one cannot actually see what sort of earthquakes are missing from the catalogue - because, of course, they are missing. The remarkable thing about the study area is that it provides the opportunity actually to examine a missing earthquake. This is an earthquake lost to the historical record, of which no description survives; yet one can infer that it took place from oblique references.

There are two such references to the event. The first is a note written in 1817 to the effect that the 9 November 1817 earthquake was the fifth or sixth shock to be felt in Kendal since June 1668 (Nicholson, 1861), implying, rather than stating, that a June 1668 earthquake occurred, which formed a sort of backstop to public memory of earthquakes in the town.

This would not be conclusive on its own were it not for another reference, from Edinburgh in 1728 (Weekly Journal, 23 March 1728, p. 2). After stating that the 1 March 1728 earthquake (see below) was felt in Peebles, Kelso, Dumfries and Berwick, it goes on to say that in some places the shock was as sensible as «that which happened before the year 1668».

Despite the use of the word «before» in the last quote, the mention of 1668 in both references appears highly significant. There is no other particular reason why two independent writers nearly 100 years apart, one in England and one in Scotland, should both pick on the unremarkable year 1668 for remembering previous earthquakes. It is to be considered as highly probable that an earthquake greater than $4 M_{L}$ occurred in or around June 1668 and was strongly felt in Kendal and the Scottish Borders; this event may have been similar to the 1970 Kirkby Stephen or the 1979 Carlisle earthquakes (Musson et al., 1984). Figure 6 shows a 


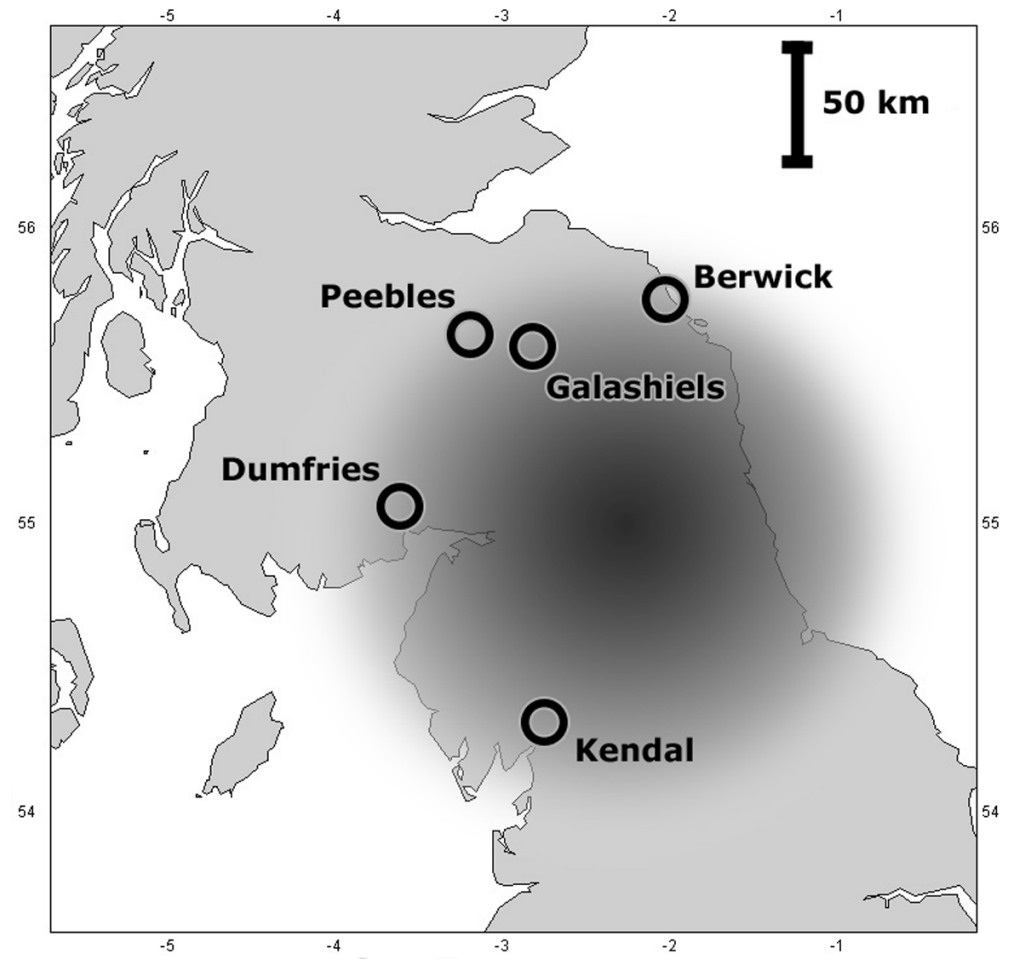

Fig. 6. Conjectured felt area for the lost June 1668 earthquake.

minimum felt area. The epicentre is so uncertain it is doubtful whether it is worth assigning coordinates to it; Musson (1994) does not.

This demonstrates that, for the 17th century, an earthquake almost certainly greater than 4 in magnitude, could occur and yet leave no direct documentary trace that has been discovered at the present day. Part of the problem is the nature of the source materials, as was previously discussed. One cannot read every surviving 17 th century letter in the hope that it may mention an earthquake, and one is somewhat dependent on the chance that reports of earthquakes will surface in the course of other research. I spoke some years ago with a local historian in Dumfries who was sure that he had once encountered a description of an earthquake in the Scottish Borders in or around 1637, but he could not recall the reference and I have never been able to find such an event.

\subsection{March 1728 Galashiels}

This earthquake is the largest event in the Borders area that is definitely on the Scottish side. Besides the 1650 earthquake already discussed, only a few other events are known in the Galashiels area (e.g., 15 March 1844) and they are very small. This earthquake was felt from Carlisle in the south to Fife in the north, and the magnitude is estimated here as $4.3 \mathrm{M}_{L}$. The infrequency of earthquakes in this area is actually commented on in some of the original reports. It was also one of only two well-determined earthquakes with epicentres in Scotland to be felt in England (the other being the 23 October 1839 Comrie earthquake).

However, there is no evidence that the intensity was higher than 4 EMS anywhere. Reports are unanimous that there was no damage, 
and no effects stronger than rattling objects are reported. This suggests that the focus may not have been shallow.

The primary sources for this earthquake are newspapers, chiefly those published in Edinburgh and London. At this period all newspapers tended to copy the same few accounts anyway. Other sources, such as Chambers (1874which is used by Davison, 1924) all refer back to newspaper accounts. The following two reports give more or less all the data.

«Edinburgh March 8. We have had some talk these several Days bygone of a small Shock of an Earthquake said to have been felt by some Persons in this City early last Friday Morning; but not Damage having thereby happen'd, it was going out of Mind, when the two following Accounts came to Hand from the South Country.

Galashiels, Selkirkshire, March 4. [Here occurs a long description of the Aurora Borealis] ... The 1st instant ...About half an Hour after Four a Shock of an Earthquake was felt all over this Place, and some Miles round; but it pleased God there was no Damage sustain'd.

Selkirk, March 3. I believe you will be surprised at the following Relation, which tho' very extraordinary, is undoubtedly true: Last Friday Morning a little before Four o'Clock, I was awakened by a Noise something like a Clap of Thunder, which, after it had roared Four Minutes, dy'd away insensibly. When it ceased, I rose out of my Bed, and look'd out at a Window, and seeing the Air clear... I concluded it had been the Morning-Drum by which I had been alarm'd. Next Morning I was told by every Body that there had been an Earthquake, and that it shook all the Houses in Town, but had done no Damage: I happen'd yesterday to be at a Gentleman's Burial, where were present a great Number of Gentlemen from all parts of the Country, an Earthquake being a very extraordinary Thing in this Part of the World, I took the Opportunity to enquire very narrowly of every one of them, if they had felt any Shaking of the Earth such a Night; all agreed they had. Some of them were abroad at the Time, and both felt the Shock and heard the Noise which follow'd; others said they were almost rolled out of Bed; and others, especially they who live to the Southwards, heard no Noise, but were dreadfully shaken in their Beds.» [London Evening Post, 14/16 March 1728, p. 2].

«Edinburgh March 12. We are informed, that the late Earthquake was felt at Peebles, Kelso, Dumfries, and Berwick, and in some places as sensibly as that which happened before the year 1668.

Galashiels, March 4. On Friday the 1st of March current, between 4 and 5 in the Morning, we felt in this Place a very sensible Shock of an Earthquake. It came from the North East, and went directly South West. It was ... attended with some Claps of Thunder: It began, as I am informed, as far as at or near Lawder, and was felt at Blamislie, Earliston, Stow, Melross, Selkirk, Hawick, Longholm, and the Length of Carlisle; how far to the North I know not. It lasted, according to some, one Minute, but most of my Acquaintance say, near three Minutes ... There have none suffered by it, but there was a strange Dancing among the Plates, Glasses \& $c$.... there was a very uncommon Sound in the Air upon the Shock of the Earth. I hear, it moved at Jedburgh too.

The above Earthquake was felt the same Day at Falkland in Fife.» [Weekly Journal, 23 March 1728, p. 2].

Only at three places (Galashiels, Selkirk and Edinburgh) can intensities be assigned (4, 4 and 3 EMS respectively), but the clustering of reports at places around Galashiels suggests that the earthquake was generally perceived in this area, and therefore the intensity was 4 EMS over this area. On this basis a conjectural isoseismal map has been constructed (fig. 7).

The epicentre appears to lie between Galashiels and Selkirk.

Some studies (e.g., Davison, 1924) give the date erroneously as 1727 - this is due to unfamiliarity with the practice of dating the start of the historical year on Lady Day (25 March).

\section{6. ? October 1746 Leadhills}

This is the earliest of a series of events felt at Leadhills and Wanlockhead, two small villages in the South of Scotland that owed their existence to historical lead mining. All these events have small felt areas, although some 


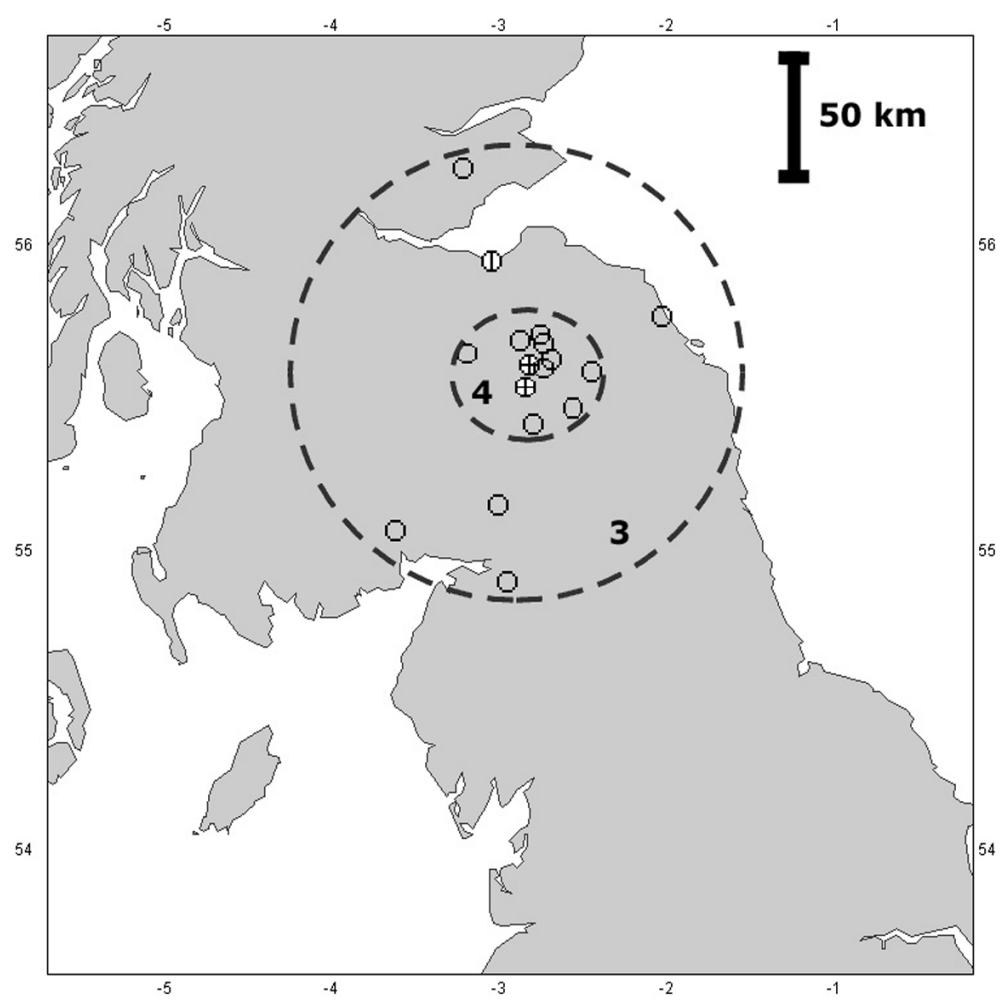

Fig. 7. Intensity and isoseismal map for the 1728 Galashiels earthquake, using standard intensity symbols. Unfilled circles indicate places where the earthquake was felt, but few or no details are known.

seem to have been quite strongly felt, especially in the mines. These are characteristics of mining tremors, and there seems little reasonable doubt that that is what these events are. Mining activity at Leadhills and Wanlockhead was quite extensive and of considerable antiquity. A mine on Glengonar Water, near Leadhills, is mentioned as operating in 1239 (Porteous, 1876; Harkness, 1925), and according to Wilson (1921) «there is little doubt that leadmining was in operation long before that time».

According to Davison (1924) and subsequent authors this earthquake occurred in 1748. This seems to be an error. There are no exactly contemporary reports known, and the earthquake is referred to in the context of the subsequent 1749 event. The original sources for latter event comment that a previous shock was felt «about the
Time the Earthquake happened at Lima» (Shirreff, 1749). It is clear that the event referred to is the 28 October 1746 Lima earthquake, which was a destructive event and made considerable impact on the British press. This fixes the date as late October or early November 1746.

The original description of this earthquake at Leadhills comes from the mining engineer Alexander Shireff, and is as follows: «I came here [Leadhills] the day after it was felt; severall people told me of it; but it was in the night time, and felt only by a few, which was the reason I took no notice of it, till the Acco ${ }^{\text {ts }}$ of that Earthquake [at Lima] came to Europe, \& found by comparing the time that it was much about the time that the Shock was felt here.» (Shirreff, 1749).

It was a common belief at this time that British earthquakes were the tail end of some 
large distant earthquake that might have travelled half way round the world.

\subsection{February 1749 Leadhills}

A good contemporary account of this earthquake survives in the form of two letters from Alexander Shirreff, the local mining engineer mentioned above. The text of the two letters is almost identical. One appeared in the Glasgow Courant [27 February 1749, p. ?] and was copied from thence by other sources; the other survives in the original MS as Hopetoun 347 (in private hands). The full text is not given here.

The salient details are as follows: at Leadhills the shock above ground was accompanied by a sound as of the falling of a house; people ran out in alarm. It was strongly felt underground; in many of the works the men ran out.
At one cut-head the shock had the effect of setting a windlass in motion. It was strongly felt by two men outdoors near the Meadowhead engine; they thought some piece of machinery had broken. One described the effects of the shock as being as if he had been struck by something. At Wanlockhead machinery shook visibly. At Penpont «the ground seemed as if going to sink, and the people all left their houses». A man crossing the Scar Water by a bridge near Penpont felt the shock, and imagined the bridge was about to fall.

These effects indicate an intensity of 5-6 EMS. There are no reports of any damage, which suggests 5 rather than 6 EMS. The felt area extends as far south as Penpont (fig. 8), suggesting the felt area may have been about $700 \mathrm{~km}^{2}$, though the sparse settlement in the area makes it impossible to estimate the eastern, western and northern extent.



Fig. 8. Places mentioned in connection with the Leadhills earthquakes of 1746 and 1749. 


\subsection{Fake or mislocated events in the Scottish Borders}

A number of spurious events in the study area are found in some previous studies. They need to be listed and explained to prevent future workers rediscovering them. The 1508 earthquake, considered here not to be a Borders earthquake, has already been discussed at length. Some minor misdatings have also been noted: the 11 April 1650 earthquake placed in 1649; the 27 April 1650 earthquake placed in 1656; the 1 March 1728 earthquake placed in 1727, and the October 1746 earthquake placed in 1748. Events not previously noted are the following: 261, 1000 and 1014, all Cumberland - these three early earthquakes appear first in Short (1749). They are fictitious, and the case against them and a class of further very early earthquakes in Britain is discussed in detail in Musson (2005).

1658, 20 January 1662, 28 January 1662, 1663, 3 April 1668, 30 January 1728, October 1728, 30 January 1729, all North of England. These appear in various studies, including Roper (1889), Davison (1924), Principia Mechanica Ltd. (1982) and Ambraseys and Melville (1983 - they state the events are not confirmed), and all trace back to Short (1749), who uses «N. England» as shorthand not for North of England but for New England. These are all early American earthquakes, some with inaccurate dates.

\section{Conclusions}

The total number of genuine earthquakes in the study area for the early historical period, up to 1750 , is only seven, of which one is a foreshock and two are mining-related. Only one of the earthquakes is known to have caused any damage. One might think that such a case history was fairly trivial. However, apart from the fact that the seismicity of this area is quite important in terms of NPP safety issues, the study presented here raises a number of issues of interest in general for studying early historical earthquakes in areas of low to moderate seismicity such as Western Europe or Eastern North-America.

In particular, one can note how important it is to pay close attention to sources. Especially, it is always advisable to treat a source document in its entirety and not rely on little extracts that someone has copied out. One could not properly interpret the medieval chronicles in this area on the basis of just the copied-out entries that mention earthquakes. Only by consideration of the entire works can one judge the significance both of the entries on earthquakes and the lack of other entries on earthquakes.

In considering whether earthquakes have been duplicated, the date and provenance of sources needs to be considered. Balfour (1825) has a different date for the 1508 earthquake than Leslie (1830), but because both were writing long after the event it is most likely that a transcription error occurred. In contrast, when Balfour disagrees with «TC» on the dates of earthquakes in 1650, a different interpretation has to be made because both sources are closely contemporaneous with the events described.

Relative dating, where one earthquake is fixed in time with respect to another, allows the correct dating of the 1746 Leadhills earthquake, and also throws up the shadow of a significant earthquake in 1668 , which is actually missing from the historical record.

Although this area was historically a border area, the usual seismological problems associated with border areas, of events being either duplicated on either side or falling down the gap between, do not seem to have been particularly prevalent, though one could make a case for the 1668 earthquake being an event that has only been traced when Scottish and English sources were compared.

After 1750, local newspapers become more widespread and the recording of earthquakes improves. In the English part of the study area quite a number of historical earthquakes are known after 1750 , including some as large as 5 $M_{L}$. Historical seismicity in the area north of the border is restricted mostly to small events, none exceeding 3.5 $M_{L}$, mostly in the area around Dumfries.

\section{Acknowledgements}

I would like to thank all the various historians I have dealt with over the years for their 
help and good company. Also thanks especially to Viviana Castelli and an anonymous reviewer who made many helpful suggestions to this paper. Parts of this paper, in a less full form, were originally published in Musson (1987), a report now out of print, and which was supported by BNFL. This paper is published with the approval of the Executive Director of the British Geological Survey (NERC).

\section{REFERENCES}

Ambraseys, N.N. and C. Melville (1983): The seismicity of the British Isles and the North Sea (SERC Marine Technology Centre, London).

ANDERSON, A.O. (1922): Early Sources of Scottish History (Oliver \& Boyd, Edinburgh).

ANON («TC») (1650): Strange newes from the North (Clowes, London).

ARNOLD, T. (Editor) (1885): Symeonis Monachi Opera Omnia (Longmans, London).

BAKER, R. (1674): A Chronicle of the Kings of England (London).

BALFOUR, J. (1825): The Hostorical Works of Sir James Balfour (Hurst Robinson \& Co., London).

BAtho, E.C. and H.W. Husbands (Editors) (1941): The Chronicles of Scotland, compiled by Hector Boece, translated into Scots by John Bellenden 1531 (Scottish Text Soc., Edinburgh)

Britton, C.E. (1937): A Meteorological Chronology to A.D. 1450 (HMSO, London)

Burton, R. (1734): A General History of Earthquakes (London).

Burton, R. (1737): Admirable Curiosities, Rarities and Wonders in Great-Britain and Ireland (London).

Burton, P.W., R.M.W. Musson and G. NeILSON (1984): Macroseismic report on historical British earthquakes IV: Lancashire and Yorkshire, BGS Global Seismol., Rep. No. 219, 2 vols.

Chambers, R. (1874): Domestic Annals of Scotland (Chambers, Edinburgh).

DAVISON, C. (1924): A History of British Earthquakes (CUP, Cambridge)

Fleming, A. (1580): A Bright Burning Beacon (Denham, London).

GILES, J.A. (Editor) (1904): Chronicle of the Kings of England, by William of Malmesbury, translated by Rev John Sharpe (Bell, London).

GransDen, A. (1974): Historical Writing in England ca. 550 to ca. 1307 (Routledge \& Kegan Paul, London).

GRANSDEN, A. (1982): Historical Writing in England II, ca. 1307 to the Early Sixteenth Century (Routledge \& Kegan Paul, London).

Hardman, C.E., N.C. Helliwell and J.S. Hopkins (1973): Extreme winds over the United Kingdom for periods ending 1971, Meteorol. Office Climatol. Memo. No. $50 \mathrm{~A}$.

HaRkNESS, J.M. (1925): Among Scotland's Lead Mines (Courier \& Herald Press, Dumfries).
HolinsHed, R. (1578): Chronicles (London).

Holinshed, R. (1806): The Scottish Chronicle (Morison, Perth).

HowletT, R. (Editor) (1884-1889): Chronicles of the Reigns of Stephen, Henry II and Richard I (Rolls Series, Longmans, London).

JEFFREY, A. (1857): The History and Antiquities of Roxburghshire and Adjacent Districts, from the Most Remote Period to the Present Time (Hope, London).

LAING, D. (Editor) (1841-1842): Letters and Journals of Robert Baillie (1637-1662), (Bannatyne Club, Edinburgh), 3 vols.

LesLIE, J. (1578): De Origine Moribus, et Rebus Gestis Scotorum (Roma).

LesLIE, J. (1830): The History of Scotland (Bannatyne Club, Edinburgh).

LeSLIE, J. (1895): The Historie of Scotland (Scottish Text Soc., Edinburgh).

MaCKAY, Æ.J.G. (Editor) (1899): The Historie and Cronicles of Scotland, written and collected by Robert Lindesay of Pitscottie (Scottish Text Soc., Edinburgh).

Maxwell, H.E. (1912): The Early Chronicles Relating to Scotland (MacLehose, Glasgow).

Musson, R.M.W. (1986): The use of newspaper data in historical earthquake studies, Disasters, 10, 217-223.

Musson, R.M.W. (1987): Seismicity of Southwest Scotland and Northwest England; with a catalogue of earthquakes within $75 \mathrm{~km}$ of Chapelcross, BGS Global Seismol., Rep. No 316.

Musson, R.M.W. (1994): A catalogue of British earthquakes, BGS Global Seismol., Rep. No WL/94/04.

Musson, R.M.W. (1996): Determination of parameters for historical British earthquakes, Ann. Geofis., XXXIX (5), 1041-1048.

Musson, R.M.W. (1998): Inference and assumption in historical seismology, Surv. Geophys., 19, 189-203.

Musson, R.M.W. (2005): Undead earthquakes, J. Seismol. (in press)

Musson, R.M.W. and P.H.O. HenNi (2002): The felt effects of the Carlisle earthquake of 26 December 1979, Scott. J. Geol., 38, 113-126.

Musson, R.M.W., G. NeILson and P.W. Burton (1984): Macroseismic reports on historical British earthquakes, I. Northwest England and Southwest Scotland, BGS Global Seismol., Rep. No. 207, 2 vols.

NeILson, G. (1980): Historical seismicity of the North Sea, in Energy in the Balance (Westbury House, London,) 120-137.

Neilson, G., R.M.W. Musson and P.W. Burton (1984): The «London» earthquake of 1580 April 6, Eng. Geol., 20, 113-142.

Nichols, J.G. (Editor) (1875): The Autobiography of Lady Jane Halkett (Camden Soc., London).

Nicholson, C. (1861): The Annals of Kendal (Whitaker, London).

OfFler, H.S. (1958): Medieval Historians of Durham (Univ. Durham, Durham).

Porteous, J.M. (1876): God's Treasure House in Scotland (Simpkin Marshall, London).

PRINCIPIA MEChanICA LTD. (1982): British Earthquakes (PML, Cambridge).

RaInE, J. (Editor) (1864): The Priory of Hexham, its Chroniclers, Endowments and Annals (Surtees Soc., Durham). 
ROPER, W. (1889): A List of the More Remarkable Earthquakes in Great Britain and Ireland During the Christian Era (T. Bell, Lancaster).

SHIRrEFF, A. (1749): Hopetoun MS 347, unpublished letter, (private collection).

SHORT, T. (1749): A General Chronological History of the Air, Weather, Seasons, Meteors, etc. (Longman \& Miller, London).

Smith, W.E.T. (1966): Earthquakes of Eastern Canada and adjacent areas, 1928-1959, Publ. Dominion Obs., 32 $87-121$

Stevenson, J. (Editor) (1855): Church Historians of England, Part II. The Historical Works of Simeon of Durham (Seeley's, London), vol. III.

Stow, J. (1601): The Chronicles of England (London).

STUCCHI, M. (1993): Through catalogues and historical records: an introduction to the project «Review of Historical Seismicity in Europe», in Historical Investigation of European Earthquakes, edited by M. STUCCHI, and J. Vogt (CNR, Milano), 1, 3-14.

Turner, W. (1696): A Compleat History of the Most Remarkable Providences, etc. (Dunton, London).

WILDE, W. (1841): Gallery of illustrious Irishmen no XIII: Sir Thomas Molyneaux, Bart., MD, FRS, Dublin University Mag., 18, 604-619.

WILSON, G.V. (1921): The lead zinc copper and nickel ores of Scotland, in Special Reports on the Mineral Resources of Great Britain (HMSO, Edinburgh), vol. 17.

(received July 7, 2004;

accepted September 23, 2004) 